\title{
“CONSTRUIR EL PARTIDO EN LAS FÁBRICAS": LA LÍNEA POLÍTICO- SINDICAL DEL PRT-ERP ANTE LA APERTURA DEMOCRÁTICA Y LA EXPERIENCIA DE SUS MILITANTES EN TRES FÁBRICAS DEL GRAN BUENOS AIRES
}

\author{
"Building the party in the factories": the political-union line of the PRT-ERP \\ in the period of democratic opening and the experience of its militants in three \\ factories of Gran Buenos Aires
}

\author{
Santiago Stavale* \\ https://orcid.org/0000-0001-9038-3815
}

\section{Resumen}

El PRT-ERP fue una organización que desde sus inicios definió a la clase obrera como "sujeto de la revolución" y concentró gran parte de sus esfuerzos en penetrar y desarrollarse en el movimiento obrero, enmarcando su accionar sindical en una estrategia general de "guerra revolucionaria". En este artículo analizamos las orientaciones con las que buscó intervenir en las fábricas durante el período 19731976, ya que fue en ese marco que aquella organización decidió rectificar la orientación militarista que venía sosteniendo hasta entonces, dedicándole mayores recursos y esfuerzos militantes al trabajo en el movimiento obrero. Por último, también analizamos la forma en que sus militantes buscaron traducir en la práctica esas orientaciones en tres fábricas del Gran Buenos Aires con el objetivo de mostrar diferentes modalidades con las que la organización intervino política, militar y sindicalmente en los establecimientos.

$$
<\text { PRT-ERP }><\text { lucha armada }><\text { lucha sindical }>
$$

\begin{abstract}
The PRT-ERP was an organization that from its beginnings defined the working class as the "subject of the revolution" and concentrated a large part of its efforts on penetrating and developing in the labor movement. Its union action was framed in a general strategy of "war revolutionary". In this article, we analyze the orientations with which it sought to intervene in the factories during the period 1973-1976. It was in this framework that the PRT-ERP decided to rectify the militaristic orientation that it had been maintaining until then, dedicating greater resources and militant efforts to work in the labor movement. Finally, we also analyze the way in which its militants sought to translate these orientations into practice in three factories of Gran Buenos Aires with the aim of showing different ways in which the organization intervened politically, militarily, and through trade unions in the establishments.
\end{abstract}

$<$ PRT-ERP $><$ armed conflict $><$ union struggle $>$

Recibido: 05/10/2021 // Aceptado: 03/02/2021

* Becario Postdoctoral del Consejo Nacional de Investigaciones Científicas y Técnicas (CONICET), Instituto de Investigaciones en Humanidades y Ciencias Sociales (IdIHCS), Universidad Nacional de La Plata, Argentina, santiagostavale@gmail.com 
Stavale. "Construir el partido en las fábricas": la línea político-sindical del PRT-ERP ante la apertura democrática y...

\section{Introducción}

Los años sesenta y setentas en Argentina estuvieron signados por un proceso de radicalización política en el que la movilización y la acción colectiva se conjugaron con un proceso de transformación de identidades políticas que dieron origen a un nuevo movimiento de oposición social y política que conformó el campo de la "nueva izquierda" (Tortti, 2014). Este proceso asumió un giro notable en el año 1969 con las manifestaciones conocidas como Rosariazo-Cordobazo-Rosariazo (Balvé; Balvé, 1989) al desatar un período de amplio cuestionamiento al orden social. Con él, se potenciaron y surgieron nuevas experiencias obreras que comenzaron a cuestionar desde las bases, en los propios espacios de trabajo, la hegemonía de las conducciones sindicales, contando en su seno con la participación de diferentes organizaciones revolucionarias. Entre estas se destacaron aquellas que buscaron hacer confluir la lucha obrera con la lucha guerrillera.

En el último tiempo han proliferado una serie de trabajos e investigaciones que se han preocupado por analizar la intervención de esas organizaciones en el movimiento obrero y problematizar el complejo vínculo entre la lucha armada y las luchas sindicales (Lorenz, 2013; Ducid, 2014; Pacheco, 2015; Casco Peebles y Lenuda, 2016; Scopetta y Torres, 2018; Stavale, 2019, 2020a, 2020b). En ese sentido, ha sido puesta en cuestión la visión sostenida por una parte importante de la bibliografía en la que las organizaciones armadas aparecen surgidas y actuando desde un vanguardismo externo al movimiento social (Ollier, 1986; Vezzeti, 2009). Por el contrario, estas nuevas investigaciones parten del hecho de que esas organizaciones fueron parte de un proceso de activación social y político más amplio del cual la clase obrera participó activamente. De este modo, se busca comprender cómo fue esa relación, atendiendo a sus tensiones, problemas y alcances.

En el presente artículo buscamos aportar a la reconstrucción de la línea sindical de una de las organizaciones guerrilleras más importantes del período: el Partido Revolucionario de los Trabajadores-Ejército Revolucionario del Pueblo (PRT-ERP). Nos interesa analizar especialmente algunas de las orientaciones que la organización planteó para intervenir en las fábricas en el escenario abierto en 1973 y la forma en que sus militantes las tradujeron en la práctica en tres fábricas del Gran Buenos Aires (Eaton Fundiciones, Rigolleau y Mercedes Benz Argentina).

Nos concentramos en aquel año ya que fue en el marco de la apertura democrática y el retorno del peronismo al gobierno que aquella organización decidió rectificar la orientación militarista que venía sosteniendo hasta entonces, dedicándole mayores recursos y esfuerzos militantes al trabajo de masas, especialmente al trabajo político entre los obreros. Además, porque fue el año en que se inició su mayor crecimiento en las fábricas, lo que la transformó en una de las organizaciones más influyentes de la "nueva izquierda" (Löbbe, 2006; Stavale, 2019).

Específicamente analizamos el modelo organizativo desde el cual la organización intentó construir "el partido en las fábricas" y desarrollar una política "multilateral" que no restringiera la intervención de sus militantes a la actividad gremial. Pero también analizamos las herramientas específicamente sindicales que impulsó así como la manera 
en que intentó vincular la lucha sindical con la lucha armada, ya que consideramos que allí estuvo uno de los sellos distintivos de su línea político sindical. Por último, reconstruimos sucintamente la experiencia militante en tres casos, con el objetivo de mostrar diferentes modalidades y estrategias con las que la organización intervino política, militar y sindicalmente en los establecimientos y, sobre todo, la manera en que sus militantes buscaron traducir en la práctica las prescripciones partidarias. Para ello utilizamos distintos tipos de fuentes: entrevistas a militantes y activistas de las fábricas; los archivos de la Dirección de Inteligencia de la Provincia de Buenos Aires (DIPBA); documentos y periódicos partidarios (centralmente, El Combatiente); documentos de otras organizaciones intervinientes, así como diarios y revistas de la época.

\section{La línea sindical perretista ante la apertura democrática: de la "desviación militarista" a "el partido en las fábricas"}

El PRT-ERP ${ }^{1}$ fue una organización que desde sus inicios definió a la clase obrera como "sujeto de la revolución" y concentró gran parte de sus esfuerzos en penetrar y desarrollarse en el movimiento obrero, enmarcando su accionar sindical en una estrategia general de "guerra revolucionaria". En ese sentido, su preocupación pasó por no limitar su intervención fabril a los repertorios sindicales clásicos, intentando combinarlos con otras formas de lucha, sobre todo, con la armada. Es que la violencia revolucionaria aparecía en el discurso perretista como uno de los vehículos principales para ayudar a dar el "salto" del plano reivindicativo al político.

Ahora bien, es de destacar que el lugar que el PRT-ERP le otorgó a la lucha sindical fue variando a lo largo de los años, pasando de considerarla como una "actividad secundaria" a transformarla, en los hechos, en uno de los pilares fundamentales de su política. Esta evolución estuvo directamente relacionada al avance en su inserción fabril y el creciente protagonismo que fue adquiriendo en los conflictos obreros (Stavale, 2019).

Debemos tener en cuenta que en sus orígenes, la organización estuvo fuertemente atravesada por el debate con aquellas corrientes y organizaciones que, rechazando la estrategia armada, centraban su intervención en el movimiento obrero haciendo eje en el aspecto sindical. Específicamente, la línea del PRT-ERP se forjo en debate con la corriente liderada por Nahuel Moreno que, a grandes rasgos, objetaba la estrategia guerrillera y sostenía que una de las tareas centrales del partido debía estar puesta en la "recuperación del movimiento sindical". En ese sentido, este último le otorgaba a la actividad gremial un carácter principal y estratégico ${ }^{2}$, que a los ojos de los perretistas lo

\footnotetext{
${ }^{1}$ El PRT-ERP fue la resultante de la ruptura del PRT en el año 1968. Este último partido había sido fundado en 1965, fruto de la fusión de dos organizaciones de orígenes sumamente distintas: Palabra Obrera - de orientación trotskista- y el Frente Revolucionario Indoamericanista Popular - de orientación indoamericanista. Los debates sobre la lucha armada - entre otros-aceleraron el proceso de diferenciación interna entre dos sectores: uno, liderado por el santiagueño Mario Roberto Santucho y otro, por el dirigente trotskista Nahuel Moreno. El primero de ellos conformó el PRT-El combatiente, y en 1970 lanzó el Ejército Revolucionario del Pueblo (ERP), mientras que el segundo formó el PRT-La Verdad, que luego -en 1972- se pasará a llamar Partido Socialista de los Trabajadores (PST). (Pozzi, 2004; Carnovale, 2011)

2 Ello se expresó en la consigna "CGT partido político de la clase trabajadora" sostenido por el PRT entre
} 
Stavale. “Construir el partido en las fábricas": la línea político-sindical del PRT-ERP ante la apertura democrática y...

llevaba a reemplazar la lucha política por la lucha reivindicativa y, sobre todo, a dejar a la clase obrera sin una estrategia de poder (PRT, 1968). A juicio de estos últimos, la supuesta sobreestimación del sindicalismo que realizaban los seguidores de Moreno traía aparejada la confusión entre las tareas partidarias y gremiales, subestimando el papel concientizador que el leninismo le había asignado al partido y dándole mayor importancia a las reivindicaciones económicas que a la "educación" de la clase obrera en las ideas del socialismo y a los "verdaderos" métodos revolucionarios de lucha. Como reacción a ello, y en el marco de la asunción de la vía armada, es que en los primeros años del PRT-ERP, puede observarse una clara "desconfianza" en los efectos que la actividad sindical podía acarrear en las concepciones de la organización. De este modo, si bien planteaba que los militantes debían atender los mínimos problemas fabriles y bregar por la defensa y reorganización de las comisiones internas y sindicatos, así como organizar oposiciones clasistas a la "burocracia sindical", consideraban a la actividad gremial como una actividad "inferior" y prepolítica, en contraposición a la actividad militar que era valorada como la expresión más elevada de la lucha de clases (Scoppetta y Torres, 2018; Stavale, 2019).

Ello se profundizó en los años posteriores a la fundación del ERP (1971-1972): en el marco de la lucha contra la dictadura y de la creciente simpatía que comenzaban a generar las acciones guerrilleras en la población ${ }^{3}$, la organización entró en una dinámica en que la lucha armada adquirió un énfasis casi exclusivo en su intervención política. En aquel período - autocalificado posteriormente de "desviación militarista"- el accionar militar tendió a autonomizarse, se multiplicaron las unidades militares y se realizaron operativos desvinculados del trabajo de masas, lo que generó un retroceso en este último plano, frenando, entre otras cosas, su inserción en el movimiento obrero (Pozzi, 2004; De Santis, 2010; Izzaetta, 2015).

Fue recién a fines de 1972 que el PRT-ERP comenzó a revertir los efectos de aquella "desviación" y, bajo la consigna "ir hacia las masas", intensificó su labor entre los trabajadores. Las primeras huellas de esta reorientación pueden hallarse en una serie de recomendaciones e instrucciones redactadas por Mario Roberto Santucho -secretario general del partido- desde la cárcel y publicada en el Boletín Interno nro. 25 de la organización (PRT, 2007 [1972], p. 113). ${ }^{4}$ A nuestro entender ésta fue una anticipación de (o más bien la transición a) lo que consideramos la etapa madura de la línea sindical perretista que se consolidó en el período 1973-1975.

1965 y 1966. Aquella política fue sostenida y defendida por Nahuel Moreno y rechazada por Mario Roberto Santucho en el I y II Congreso de la organización.

3 Esta aceptación se ve reflejada por los resultados de una encuesta realizada por IPSA en noviembre de 1971, que daban cuenta de que el $45 \%$ de la población bonaerense justificaba la violencia guerrillera, mientras que en Rosario el porcentaje era del 51\% y en Córdoba alcanzaba al 53\% (O'Donell, 1982, p. 464).

${ }^{4}$ El escrito y sus orientaciones tuvieron como motivación primera el triunfo de la Lista Marrón en SMATA Córdoba, en abril de 1972, de la cual el PRT-ERP formaban parte. 
El escrito desmenuzaba cada uno de los aspectos, tareas e iniciativas que no podían faltar en el desarrollo de ningún frente fabril..$^{5}$ Los objetivos apuntaban a: "la construcción del Partido, la formación de células, estrecha ligazón con las masas, aumento constante de nuestra influencia, lucha por la dirección del movimiento en su conjunto, fortalecimiento y crecimiento del ERP, amplia difusión de nuestra línea, nuestras consignas, el nombre de nuestra organización y nuestra bandera" (PRT, 2007 [1972], p. 113). Para ello, la militancia fabril perretista debía partir de la lucha reivindicativa y concentrarse en influenciar al personal activo, es decir, a la base obrera.

La lucha sindical era el primer aspecto que desarrollaba el documento. Según Santucho, los militantes dedicados a esta tarea debían conocer "al dedillo" los problemas de la fábrica, así como la situación de cada una de sus secciones, para intervenir en todas las luchas reivindicativas que surgieran. Además instaba a consolidar y desarrollar una “corriente clasista, con el programa 'por la guerra y el socialismo' como eje de un amplio frente sindical antiburocrático, antidictatorial y antipatronal, que se proponga lograr la dirección del movimiento obrero" (PRT, 2007 [1972a], p. 113).

Otro de los temas que trabaja el documento es el de la "propaganda y agitación". En este punto insistía en la difusión de folletos y de la línea partidaria, y en el desarrollo de la propaganda armada ligada a las luchas reivindicativas de las fábricas. Por otro lado reclamaba regularizar la publicación de un boletín fabril con un intervalo semanal, mientras que en el aspecto organizativo instaba a construir distintos tipos de organismos al interior de los establecimientos, como las células partidarias y escuadras o células militares del ERP así como círculos de simpatizantes y colaboradores.

Creemos que ésta fue la base desde la cual la organización perfeccionó su estructura organizativa y enriqueció su línea sindical cuando, en tiempos democráticos, se lanzó a construir "el partido en la fábrica". Es que ante la convocatoria a elecciones anunciada por la dictadura, la organización evaluaba que la extensión de las posibilidades legales y semilegales permitiría generalizar la lucha reivindicativa, y que ello se expresaría fundamentalmente en una tendencia a "recuperar" sindicatos. En ese sentido, preveían que la instauración de un gobierno peronista, si bien en un principio generaría desorientación en la clase obrera y el pueblo, alentaría la lucha por las reivindicaciones inmediatas. ${ }^{6}$

En función de ello calculaban que el desencadenamiento de las movilizaciones partiría, fundamentalmente, del reclamo por aumentos salariales, por lo que "lograr buenos puntos de apoyo en el movimiento sindical a nivel local y nacional" pasaba a ser una tarea de primer orden:

5 El PRT-ERP denominaba frente fabril a una fábrica grande o a un grupo de fábricas de la misma industria, ubicadas en una misma zona que por algunas circunstancias se hacía necesario tomarlas de conjunto (PRT, 2010 [1974a]).

6 "Roto el dique de contención de la Dictadura, las masas se lanzarán decididamente por la brecha abierta a recuperar sus conquistas, a mejorar su nivel de vida. Pero la situación económica impedirá concesiones importantes y el choque violento entre las masas y el nuevo gobierno parlamentario será inmediato, los políticos burgueses deberán recurrir a corto plazo a la represión, a la intervención de los militares.” (EC, 70, 7/72). 
Stavale. "Construir el partido en las fábricas": la línea político-sindical del PRT-ERP ante la apertura democrática y...

\begin{abstract}
Todo lo que avancemos para ganar influencia sindical a nivel fabril (delegados) y sindical (sindicatos), todos nuestros avances en la construcción de nuestra corriente clasista por la guerra y el socialismo, todos nuestros avances en el frente antiburocrático, serán decisivos, para influir directamente en las movilizaciones como para darnos una estrategia realista de lucha contra la burocracia. (PRT, 2006 [1972b], p. 280)
\end{abstract}

Como señalamos, si bien en los años previos la lucha sindical había quedado en un segundo plano, en esta nueva etapa aparecía como una actividad fundamental para lograr la inserción en las principales fábricas y darle un cauce revolucionario a las lucha obreras que se desatarían. Así fue que, bajo el lema de "formar centenares de células fabriles", y en el marco de un gobierno peronista, la organización buscó penetrar en las principales fábricas del país.

\title{
Definiciones ante el triunfo electoral peronista
}

El 11 de marzo de 1973 la fórmula peronista encabezada por Héctor J. Cámpora y Vicente Solano Lima, finalmente, se impuso en las elecciones convocadas por el gobierno de facto saliente. Luego de 18 años de proscripción y en medio de un clima de efervescencia y radicalización política creciente, el peronismo retornaba al gobierno abriendo un período de restauración democrática que significó un gran desafío para las organizaciones revolucionarias, en general, y para el PRT-ERP, en particular. Es que, contra los pronósticos, análisis y expectativas perretistas, la apertura electoral había demostrado que la lealtad y la filiación política peronista de gran parte de la clase obrera argentina seguían siendo muy fuertes. ${ }^{7}$ De modo que para esta organización, que cuestionaba la identidad peronista y se había forjado en la lucha armada contra la dictadura, la nueva coyuntura abierta la obligaba a repensar y reorientar su intervención política.

En términos generales, enfrentó la nueva situación bajo la decisión de aprovechar al máximo los intersticios legales abiertos, para expandir su influencia e inserción en las masas, sin abandonar la lucha armada. ${ }^{8}$ En ese sentido, lo que se proponían era encontrar

\footnotetext{
7 En sus análisis, los trabajadores y el pueblo aparecían sin esperanzas de cambio y sin interés en las elecciones. Sus valoraciones estaban atravesadas por un contexto de auge de la movilización obrera en la que las corrientes clasistas crecían en distintas zonas y gremios y grandes sectores de la población demostraban amplia simpatía hacia las organizaciones armadas. De hecho, en base a ello, la organización analizaba que la clase obrera estaba viviendo un proceso de "revolución ideológica" en el que, básicamente, estaba rompiendo con el peronismo y comenzando a abrazar la causa revolucionaria. (EC, 75, 3/73)

8 En esta definición se jugaban tres certezas: por un lado, que el gobierno que había surgido de las elecciones tenía el único objetivo de salvar al capitalismo de su crisis. Es que los perretistas consideraban que la salida democrática pergeñada por la dictadura militar -a través del Gran Acuerdo Nacional- y el retorno de peronismo al gobierno, eran las últimas cartas que tenían las clases dominantes para frenar la radicalización política, encauzar la conflictividad social institucionalmente y dividir y aislar a las organizaciones revolucionarias. Por otro lado, estaban convencidos de que el repliegue de las FFAA era táctico y no definitivo, por lo que había que continuar combatiéndolas para no permitirles retomar la iniciativa. Por último, consideraban que la actividad guerrillera apuntalaba y estimulaba la movilización de las masas y era la garantía del proceso de democratización.
} 
una complementariedad y un equilibrio entre la lucha armada y la lucha político-legal en todos los planos. En cuanto al trabajo en el movimiento obrero, como veremos, el llamado era a estrechar el vínculo entre la actividad legal y la actividad clandestina y, de ese modo, intervenir en las luchas reivindicativas previstas haciéndolas avanzar hacia enfrentamientos de mayor gravitación política.

Las estimaciones que había hecho la organización sobre las movilizaciones que se producirían ante la apertura democrática se confirmaron inmediatamente. Así, tan sólo desde el 11 de marzo hasta el 25 de mayo (día de asunción del nuevo gobierno), se contabilizan 320 conflictos obreros en todo el país (Izaguirre y Aristizábal, 2002). Como era de esperarse, los perretistas se hicieron eco de estas luchas y aunque eran conscientes de que estas primeras refriegas y movilizaciones obreras no se dirigirían hacia el gobierno, definieron apuntalarlas como tarea fundamental.

Ahora bien, la importancia que adquirieron las luchas sindicales en la política del PRT-ERP no se debió solamente al entusiasmo por esta ola de movilizaciones, sino también al hecho de que uno de los pilares fundamentales del proyecto gubernamental, el Pacto Social, se dirimía en gran parte en aquel terreno. Aquel acuerdo, que suponía el congelamiento de precios y salarios y, por ende, la suspensión de las negociaciones colectivas, fue inmediatamente rechazado por el PRT-ERP que, rápidamente, comprendió que las movilizaciones por reivindicaciones gremiales (sobre todo la salarial) eran claves para enfrentar a los trabajadores con el gobierno. La otra política gubernamental de peso, estrictamente vinculada a lo sindical, que impugnaron los perretistas (junto al resto de las organizaciones de izquierda marxista y peronista) fue la Ley de Asociaciones Profesionales, la cual le otorgaba mayor poder a las conducciones sindicales en detrimento de las expresiones combativas. Para enfrentar ambas iniciativas, la organización buscó intensificar la movilización de los trabajadores, fomentando procesos asamblearios y de base en cada fábrica y apostando a la unidad de las distintas expresiones antiburocráticas. Es que, a los ojos de los perretistas, si se lograba articular las demandas obreras en torno al rechazo a aquellas medidas, sería posible acelerar el proceso de ruptura definitiva entre la clase obrera y el peronismo que, a su juicio, más tarde o más temprano se produciría.

No obstante, la ecuación no era sencilla y los desafíos eran múltiples, ya que no sólo debían enfrentarse al peso de la "burocracia sindical" en las fábricas sino también al notable crecimiento del peronismo revolucionario, sobre todo de Montoneros, que también imponía límites a su influencia y a sus objetivos. Es que si bien con estos últimos compartían una causa común que les permitía coordinar y articular por la base en algunos establecimientos, al mismo tiempo, tenían diferencias estratégicas que obturaban acuerdos más allá de los mismos: si el PRT-ERP buscaba garantizar la "independencia del movimiento obrero" y el enfrentamiento directo con las medidas gubernamentales, Montoneros abogaba por la disputa en el seno del movimiento peronista y medía la beligerancia de sus posiciones en función de sus compromisos con el gobierno (Pacheco, 2015; Stavale, 2017). Aquello, entonces, obligaba al PRT-ERP a esforzarse por mantener un difícil equilibrio entre el combate ideológico contra el peronismo y la unidad de 
Stavale. "Construir el partido en las fábricas": la línea político-sindical del PRT-ERP ante la apertura democrática y...

acción con sus sectores revolucionarios. Para ello la organización agudizó la polémica con estos sectores a la par que, sin demasiados resultados, redobló los esfuerzos por concretar mayores niveles de unidad (Stavale, 2017).

Sin embargo, la preocupación principal del PRT-ERP pasaba por el crecimiento que adquiriera la conflictividad obrera y la capacidad que tenía para dirigir e influir en ellos. A sus ojos, allí se jugaba la oportunidad de quebrar las "ilusiones populistas" generadas por el gobierno. En ese sentido afirmaban:

El resultado del presente auge de masas dependerá de quien logre asumir finalmente la dirección, dependerá de si el peronismo burgués logra imponerse y controlar o si por el contrario, el proletariado revolucionario, organizado en el partido marxistaleninista, es capaz de librarse del canto del cisne de la burguesía, de sus engaños, desarrollar una política independiente de clase y acaudillar, movilizar tras de sí a las amplias capas populares, al campesinado pobre, los pobres de la ciudad y la pequeñoburguesía urbana.

La clave para lograr que la clase obrera se coloque a la cabeza de la lucha revolucionaria, conquistando la dirección del proceso, es la influencia, madurez y consistencia de su Partido Revolucionario. Esto se logra básicamente centrando el esfuerzo en la construcción en las fábricas (...). (EC, 88, 31/8/73)

Esto implicaba multiplicar las tareas en "la batalla por la consolidación y desarrollo" de la organización en los centros fabriles, lo que se materializó en el llamado a construir "el partido en las fábricas". Como plantean Scoppetta y Torres (2018), ésta fue una de las líneas fundamentales de la política perretista en el período post-electoral, con el que se buscó reconstruir el partido, luego de recorrer la experiencia del militarismo, fortaleciéndolo y multiplicándolo en base a la clase obrera, como piedra angular de su estrategia de poder. Básicamente, con ello se buscaba de multiplicar la inserción fabril y "profesionalizar" los métodos de organización y militancia, lo que significaba la construcción de una estructura definida al interior de los establecimientos, la especialización de las tareas y el desarrollo de herramientas específicas para cada una de ellas.

Es de destacar que si bien esta política no fue suficiente para quebrar la hegemonía peronista entre los trabajadores, sí fue sustancial para que aquel partido se transformase en una de los más influyentes de la nueva izquierda en el movimiento obrero, logrando en muy poco tiempo (1973-1976) insertarse en la mayoría de los centros productivos del país y ser parte protagonista de varios de los conflictos sindicales más sobresalientes del período (Stavale, 2019).

A continuación, intentaremos reconstruir cuáles fueron los pilares fundamentales de esta política para luego analizar la manera en que se implementó en la práctica. 


\section{El partido en las fábricas}

Como dijimos, la disposición de construir el partido en las fábricas suponía "profesionalizar" la militancia, es decir, ordenar y organizar de manera sistemática y con criterios estandarizados, los métodos, la estructura y las herramientas políticopartidarias al interior de los establecimientos. De este modo, desde la dirección se planteó un modelo ideal de cómo debía desarrollarse la estructura organizativa y sus respectivos organismos y de cuales debían ser las tareas militantes que cada uno de ellos debía llevar adelante.

La apuesta principal estaba en la "especialización” de la militancia en las distintas tareas partidarias (principalmente la sindical, la militar y la política), ya que se partía de la idea de que un mismo grupo de militantes no podía desarrollar cada una de ellas con la profundidad que merecían. Así, en febrero de 1973, el partido intentaba solidificar los criterios que había vertido Santucho hacía casi un año. En el Boletín Interno nro. 37 el Buró Político perretista "reiteraba conceptos" acerca de cómo organizarse en los frentes de masas, haciendo énfasis nuevamente en el frente fabril, para lograr un desarrollo "armónico" de la organización (PRT, 1973).

Para ello, la militancia debía esforzarse por construir de manera integral distintos tipos de células ${ }^{9}$ : células de masas, células militares, células de propaganda $\mathrm{y}$, eventualmente, células de trabajo legal. El desarrollo de estos tres organismos debía ser la garantía para evitar caer en el "sindicalismo", el "militarismo" o en desarrollo "superficial de la organización".

La célula de masas era aquella que se ocupaba de todo lo referido a la lucha reivindicativa, entre lo que figuraba el impulso de agrupaciones sindicales y demás instrumentos que dispusiera la organización para esta tarea. No obstante, una vez consolidada la célula, la primera tarea de sus militantes debía ser construir, en base a la incorporación de obreros de la fábrica sobre la que se estuviera trabajando, las otras dos células consideradas fundamentales: la militar y la de propaganda. La célula militar debía ocupar el $80 \%$ de su tiempo en la realización de acciones ligadas a la fábrica y a sus barrios lindantes aunque también debía destinar un $20 \%$ a la colaboración activa con tareas de propaganda. ${ }^{10}$ La célula de propaganda, a su vez, debía encargarse de la distribución de todos los materiales de propaganda del partido, y se debía encargar de redactar e imprimir, en estrecha colaboración y relación con la célula de masas, los boletines fabriles. ${ }^{11}$

\footnotetext{
${ }^{9}$ Las células eran el organismo básico del partido, la instancia donde se organizaban los militantes, en la que discutían la línea política de la organización y establecían las líneas de acción en un frente de masas determinado. De modo que la existencia de una éstas era el primer requisito para comenzar a edificar el partido en una fábrica y la construcción de otras nuevas (y especializadas en distintas tareas) el paso siguiente.

${ }^{10}$ Fundamentalmente, se le exigía que ayudara operativamente al ingreso de periódicos, boletines, volantes y todos los materiales que dispusiera la célula de propaganda.

${ }^{11}$ Los boletines fabriles eran una herramienta de propaganda partidaria que buscaba ligar los problemas cotidianos de la fábrica con las apuestas políticas e ideológicas de la organización. Según Luis Mattini "era lo que expresaba la política del partido adentro de la fábrica". En ese sentido, para el PRT-ERP se trataba del "arma político-ideológica clave para el afianzamiento, consolidación de los comités de fábricas", y su presencia era una muestra cabal del nivel de inserción e influencia logrado por la organización en las plantas (EC, 205, 26/2/76; Entrevista a Mattini por el autor, Buenos Aires, 2017.)
} 
Stavale. "Construir el partido en las fábricas": la línea político-sindical del PRT-ERP ante la apertura democrática y...

Una vez desarrollados estos tres organismos, y si había posibilidades, debía construirse la célula de trabajo legal, pensada para organizar a obreros interesados en el trabajo político amplio y barrial, pero también para organizar ollas populares en los barrios lindantes así como la solidaridad de personalidades políticas y otras organizaciones legales en el marco de los conflictos sindicales. ${ }^{12}$

Este conjunto de organismos y actividades posibles ${ }^{13}$ surgían de la idea de que la clase obrera poseía energías inagotables, y que para aprovecharlas era necesario que estén dirigidas por un fuerte partido proletario que las organice. En ese sentido la ecuación era sencilla: "el partido es como un dínamo, las tareas son comparables a las lámparas. Si el dínamo es suficientemente poderoso, las lámparas se encienden" (PRT, 1974a).

Alrededor de las células, a su vez, debía organizarse el "radio de influencia" del partido, es decir el conjunto de personas a las que los militantes "atendían" y les hacían llegar la línea de la organización. Estas personas podían cumplir algunas tareas dependiendo del nivel de compromiso que estaban dispuestas a asumir, por lo que las células las organizaban y jerarquizaban como "simpatizantes", "contactos" o "lectores". ${ }^{14}$

Por último, para completar la estructura partidaria, se planteaba la construcción de una dirección al interior de los establecimientos: el Comité Fabril. En el organigrama perretista éste debía funcionar como un órgano dirigente que reuniera a los responsables de cada una de las células para coordinar las tareas y la línea de intervención de la organización en todos sus aspectos, además de ser un enlace con las direcciones regionales y nacionales del partido. El Comité Fabril debía elaborar un plan de funcionamiento del conjunto de las células, adecuado a la situación concreta de la fábrica. A su vez era el encargado bregar por la "armonización" de las distintas tareas, velando por una buena distribución de los recursos militantes (EC, 158, 12/3/75).

Según Luis Mattini, los Comité Fabriles debían ser la "columna vertebral" del partido en la fábrica y como la autoridad máxima en ese ámbito "perseguía el objetivo de que cada especialidad estuviera convenientemente 'balanceada' para la combinación de las tareas y efectivizara el conocido postulado "combinar todas las formas de lucha"

\footnotetext{
${ }^{12}$ La importancia que fue adquiriendo la tarea sindical en el desarrollo del partido llevó a que en el año 1975 el Buró Político autorizara la construcción de células sindicales diferenciadas de las células de masas.

${ }^{13}$ Como parte de las resoluciones del Comité Central partidario, en septiembre de 1974, se publicó un documento titulado "Las tareas centrales del Partido", en el que se proponían siete recomendaciones para la "construcción del partido en las fábricas". En él se insistía, entre otras cosas, en la necesidad de construir las células estructurales (de masas, militar, de propaganda y legal) y proponía, en la medida de lo posible, organizar otro tipo de células y "subequipos de masas" que tomarán nuevas tareas, o tareas más específicas (EC, 134, 11/9/74).

${ }^{14}$ Los simpatizantes cotizaban dinero mensualmente, recibían El Combatiente y debían vender al menos un ejemplar del mismo; el "contacto" era alguien que también funcionaba como correa de trasmisión de la línea del partido pero que no tenía un vínculo tan formal y regulado como el simpatizante; y el "lector" era todo aquel que recibía "religiosamente" la prensa partidaria y coincidía con las posiciones de la organización. En julio de 1975, el Comité Central modificó los estatutos y reorganizó a las células por tríos, un número que permitiría garantizar una mejor coordinación y ejecución de las tareas. El trío reemplazaba a las células organizadas con cuatro, cinco o seis militantes y buscaba reforzar la especialización y profesionalización de los militantes (EC, 181, 3/9/75; EC, 194, 3/12/75)
} 
(Mattini, 2007, p. 242). Pero tampoco debía forzarse su construcción si no era el resultado de un desarrollo genuino y necesario. De modo que funcionaron como una meta y una orientación a seguir para la militancia fabril perretista. El hecho de que se tratara de modelo difícilmente alcanzable, por el nivel de desarrollo y especialización y por la cantidad de militantes que requería, apuntaba a que la militancia fabril no perdiera la iniciativa ni se conformara con algunos logros alcanzados.

De hecho, como veremos, en la práctica no logró ser garantizado en todos los casos ya que la militancia fabril perretista tendió a ajustar la estructura organizativa en función de los límites y las posibilidades que brindaba la realidad de cada fábrica.

\section{Lucha sindical y lucha armada}

En cuanto a lo específicamente sindical, la herramienta considerada "casi imprescindible" era la agrupación, instrumento para disputar y "recuperar" los organismos de representación obrera, dinamizar la actividad allí donde se los hubiera conquistado y, al mismo tiempo, debía servir para incorporar a aquellos trabajadores dispuestos a asumir mayores compromisos y definiciones (PRT, 1969). Teóricamente, era concebida como el espacio donde se unificaba la vanguardia obrera con "lo mejor de las masas" de una fábrica, es decir, con trabajadores dispuestos a organizarse para luchar por mejores condiciones de vida, contra la burocracia, por la democracia sindical y la independencia del estado (EC, 155, 17/2/75).

Ahora bien, una de las advertencias principales que realizaba la organización a sus militantes era que las agrupaciones no debían ser confundidas con organismos partidarios. Debido a su carácter "eminentemente económico", uno de sus rasgos principales debía ser la amplitud. En las agrupaciones tenían que organizarse la mayor cantidad de obreros posibles, independientemente de su adscripción o identidad política, por lo que los esfuerzos debían estar puestos en no "sacar línea de la galera", ni sectarizarla forzando sus definiciones más allá de "la conciencia política de las masas" (EC, 155, 17/2/75). En ese sentido, la influencia del partido debía darse mediante un paciente trabajo de los militantes partidarios que actuaran en su seno.

Por otro lado, en la búsqueda por construir una corriente clasista, combativa y antiburocrática a nivel nacional, estas agrupaciones debían tender a nuclearse en instancias federativas más abarcadoras. Ese fue el sentido que la organización le dio al Movimiento Sindical de Base (MSB). Fundado en julio de 1973, aquel movimiento se propuso (i) luchar contra la ofensiva ideológica y política de la "burocracia sindical", (ii) disputar y democratizar las herramientas gremiales y (iii) promover la movilización y la independencia del movimiento obrero, en función de un programa de denuncias, reivindicaciones permanentes e inmediatas que iban desde el aumento generalizado de salarios al control obrero de la producción. El MSB se erigió como la apuesta más importante del PRT-ERP, a nivel sindical, e intentó transformarse en la "viga maestra" que articulara la mayor parte de su trabajo a nivel nacional. ${ }^{15}$ También, a través del

\footnotetext{
${ }^{15}$ En su II Plenario, realizado en Córdoba en abril de 1974, participaron cerca de cinco mil trabajadores en
} 
Stavale. "Construir el partido en las fábricas": la línea político-sindical del PRT-ERP ante la apertura democrática y...

mismo, buscó desarrollar un marco de alianzas más amplio que le permitiera nuclear a otras organizaciones, así como alinear agrupaciones clasistas independientes y dispersas (Stavale, 2020b).

Ahora bien, como dijimos, una de las preocupaciones principales de aquel partido era que su política fabril no pasara casi exclusivamente por la militancia sindicallegal. Como vimos, esta fue una inquietud constante desde sus orígenes y, sobre todo, en tiempos democráticos en los que las posibilidades legales eran mayores y podría existir una "tentación" a concentrar todos los recursos militantes en ello. En ese sentido fue que planteó su política de equilibrios entre lo legal y lo clandestino, esto es, entre la lucha armada y las demás actividades. A nivel sindical, ello se plasmó en el impulso, a la par del MSB y las agrupaciones, de una tendencia sindical clandestina y armada: la Tendencia Obrera Revolucionaria 22 de Agosto (TOR “22-8”) (EC, 77, 4/73).

Lanzada en enero de 1973, ésta había sido pensada como una herramienta que reuniera a los trabajadores que simpatizaran con la lucha armada y con el socialismo pero que no necesariamente estuvieran dispuestos a organizarse en el PRT-ERP. La misma tenía la tarea de organizar la "violencia de masas", respondiendo mediante acciones armadas a los golpes represivos de la patronal y/o la burocracia sindical en momentos en que la actividad legal de los sindicatos fuese clausurada o seriamente restringida. En ese sentido debía oficiar como un escalón organizativo que permitiera reunir a los trabajadores "más avanzados" del amplio campo de la lucha gremial y que, a su vez, oficiara de "cantera de militantes" para el partido (PRT, 1974b).

Ahora bien, finalmente la ampliación de las posibilidades legales hizo que, en la práctica, el trabajo en los sindicatos, en las comisiones internas y cuerpos de delegados fuera el que mayores demandas y esfuerzos requería, al mismo tiempo que el que mayores resultados daba. En ese sentido, las agrupaciones legales (o los organismos de base y las listas sindicales) fueron las herramientas principales desde las cuales intervino la organización a nivel sindical. De modo que la TOR “22-8” no logró desarrollarse. Es que, en los hechos, intentó ocupar un lugar intermedio, entre la agrupación sindical

representación de ciento veinte agrupaciones sindicales, sindicatos y comisiones internas. Sin embargo, su crecimiento dependió de las diferentes regionales siendo Córdoba, la más importante. Organizaciones como el Grupo Obrero Revolucionario (GOR), Orientación Socialista, Liga Espartaco, el Partido Comunista Marxista Leninista (PCML) participaron del movimiento; el cual también contó con la participación y adhesión, en sus actos, del Frente Revolucionario Peronista, las Fuerzas Armadas de Liberación (Columna Lescano-Polti-Taborda, Columna América en Armas y Columna Che Guevara), la Juventud Radical Revolucionaria y la sección tucumana del Peronismo de Base. En su programa, la lista de reivindicaciones permanentes consignaba la exigencia de la derogación de la legislación represiva, el mejoramiento de las condiciones de vida y de trabajo (en las que figuraba principalmente el reclamo por vivienda digna, fuentes de trabajo, salud gratuita y derechos cívicos) y el ejercicio de la democracia sindical (este último se erigía como punto central). Por último, se incorporaban las exigencias del control obrero de la producción, la libertad a los presos políticos, la convocatoria de las comisiones paritarias nacionales para la discusión de los convenios colectivos, el aumento de los salarios y el retiro de las fuerzas policiales de los lugares de trabajo. Para un estudio en detalle de dicha experiencia ver Stavale (2020b). 
y el ERP, que no necesariamente existía ya que, como indica Luis Mattini, quienes simpatizaban con la lucha armada terminaban incorporándose directamente al partido. ${ }^{16}$

Efectivamente la intervención militar en las fábricas estuvo a cargo del ERP. A través de sus unidades militares la organización realizaba distintos tipos de acciones de propaganda armada. ${ }^{17}$ Éstas, generalmente, estaban ligadas a conflictos sindicales o a reivindicaciones obreras de distinta índole, dirigidas a los establecimientos en los que se tenía trabajo político o en las que el partido quería ingresar. Comprendían desde atentados a fábricas o a sus dueños (quema de automóviles, quema de stock, atentados con explosivos, etc.), secuestros de gerentes o dueños de empresas (apuntados a resolver algún conflicto o a satisfacer demandas de los trabajadores), intimidaciones y advertencias a capataces, jefes de seguridad o burócratas delatores, "alcahuetes" u hostigadores de obreros, hasta intervenciones directas en asambleas, tomas de guardias para repartir volantes o prensas, tomas de colectivos o trenes cargados de trabajadores, tomas de fábricas y "repartos" (secuestros de camiones con ropa o alimentos para distribuirlos en poblaciones aledañas). Con las acciones de propaganda armada los perretistas buscaban poner en práctica, a pequeña escala, una muestra del poder dual que revirtiera por un momento la autoridad dentro de la fábrica, infundiera miedo entre los capitalistas e inspirara confianza en los trabajadores, quienes, en muchos casos, lo recibían como un acto de justicia y venganza ante una cotidianeidad hostil de explotación, vigilancia y disciplinamiento (Scoppetta y Torres, 2014, p. 138). Al mismo tiempo, tenían el objetivo de difundir la línea y la sigla de la organización, mostrar su poder de fuego, así como sumar apoyos y captar nuevos militantes.

Ya desde la constitución del ERP, la propaganda armada se resaltaba como una de las herramientas fundamentales para el trabajo de masas y sindical y también, como tarea especial de las células militares, que, como dijimos, debían construirse al interior de las fábricas. ${ }^{18}$ Acciones de este tipo ayudaron a prestigiar a la organización y en muchos casos permitieron iniciar un trabajo político allí donde aún no lo había, ya que le permitía tomar contacto y acercar a los trabajadores que simpatizaban con la lucha armada o tenían las posiciones cercanas al partido. Ese fue el caso, por ejemplo, del emblemático secuestro de Stanley Sylvester, cónsul británico y gerente de la planta Swift de Rosario. La acción se dio en el marco de una política patronal de despidos masivos, cierres temporarios de la planta, etc. y tuvo como objetivo lograr cumplir muchas de las exigencias, necesidades y demandas históricas de los trabajadores de la

\footnotetext{
${ }^{16}$ Entrevista a Luis Mattini por el autor, Buenos Aires, 2017. (Para un análisis detallado de la experiencia de la TOR "22-8" ver Stavale, 2019.

${ }^{17}$ Como resalta Inchauspe (2007), esta política estaba inspirada en la experiencia de guerra de guerrillas vietnamita. Siguiendo a Ernesto "Che" Guevara, la misma tenía el objetivo de mostrar el "poderío" y la "imbatibilidad" del ejército revolucionario que sumido en "el gran mar del pueblo como pez en el agua (...) catalizaba las masas con su presencia" (Guevara, 1964).

18 "Las células básicas del Partido tendrán como preocupación fundamental en el terreno militar la aplicación de una línea de masas por el Ejército Revolucionario del Pueblo y contribuirán a ella mediante un estrecho contacto con dicha organización, aportando informes y transmitiendo la opinión y estado de ánimo de las masas a fin de lograr su movilización con operaciones de propaganda armada" (PRT, 2004 [1970], p.325)
} 
Stavale. "Construir el partido en las fábricas": la línea político-sindical del PRT-ERP ante la apertura democrática y...

planta. No sólo la acción fue exitosa, sino que significó un antes y un después para la organización en la zona, ya que generó profunda simpatía entre los trabajadores de la fábrica y la población de la zona sur de Rosario; además, permitió que la organización potencie su trabajo político y sindical generando contactos e incorporaciones de nuevos trabajadores a sus filas (Pozzi, 2004, p. 253).

Ahora bien, estas acciones conllevaban un alto riesgo si en ella no imperaba el "criterio político", no se respetaban los tiempos del trabajo sindical y no se trabajaba de manera coordinada y consultiva con la militancia fabril perretista. Así, en algunos casos, podían llegar a hacer retroceder el trabajo sindical que se estaba desarrollando, como en el caso de la usina de Villa Revol en Córdoba. Allí una acción del ERP en la puerta de la fábrica (un comando guerrillero atacó a un patrullero) dispersó a los obreros, congregados a movilizarse luego de una asamblea en la que se había votado una medida de lucha ${ }^{19}$. Esto generó desconcierto entre los trabajadores y un costo político para la militancia perretista dentro de la fábrica (Pozzi, 2004, p. 184).

Como veremos a continuación, esta práctica y todas las orientaciones antes reseñadas estuvieron condicionadas por la realidad de cada establecimiento, y fueron traducidas por los militantes en función de sus necesidades, posibilidades y experiencias. De este modo no siempre se eligió o se pudo desarrollar una agrupación sindical así como tampoco se priorizó la intervención militar en los conflictos. Así, la línea partidaria fue configurándose en la práctica, donde la militancia fabril perretista, aunque hilvanada por criterios y orientaciones similares, fue conformando distintas modalidades y estrategias de intervención política, militar y sindical con resultados políticos diferentes.

\section{Tres fábricas, tres modalidades: los casos de Eaton Fundiciones, Rigolleau y Mercedes Benz Argentina}

\section{Eaton Fundiciones: un caso modélico}

Eaton Fundiciones era una fábrica de capitales norteamericanos que había sido instalada en el año 1962 en la localidad de José C. Paz, al norte del Gran Buenos Aires. Dedicada a la producción de ejes, diferenciales y otros materiales para la industria automotriz, la empresa contaba con dos plantas (Eaton Ejes y Eaton Fundiciones), ubicadas en el mismo terreno ${ }^{20}$. Los trabajadores estaban encuadrados bajo el SMATA aunque cada planta tenía una Comisión Interna y un Cuerpo de Delegados diferentes, por lo que las reivindicaciones y la representación gremial eran distintas. Por su parte, Eaton Fundiciones contaba con 300 obreros y se dedicaba a la fundición de metales, por lo que sus principales reclamos pasaban por las condiciones de insalubridad a la que

\footnotetext{
${ }^{19}$ El responsable de la acción fue Juan Manuel Murúa, conocido como el Flaco Caña, militante partidario y destacado combatiente del ERP. Murúa fue compañero de trabajo de Agustín Tosco, quién lo definió en una de sus cartas como "pollo de su gallinero" y quien no habría reparado en críticas ante dicha acción: "Al otro día, Tosco lo llamó al Caña y le hizo una durísima crítica, más que eso fue un reto a uno de los suyos que se había mandado 'un cagadón', para decirlo en tono cordobés.” (De Santis, 2010, p.378)

${ }^{20}$ Además la empresa contaba con otra planta de fundiciones, ubicada en la localidad de Tortuguitas, llamada Eaton Metalúrgica.
} 
estaban expuestos ${ }^{21}$. Su caso es paradigmático por los niveles de influencia que logró el PRT-ERP en poco tiempo.

La presencia de la organización en aquella planta se remonta al año 1972, momento en que Marcelo Luis “el Flaco” Panizza se incorporó a la organización. El contacto con el PRT-ERP no se dio al interior de la fábrica sino en Devoto, barrio donde vivía Panizza. Un amigo suyo que militaba en la organización, al enterarse de su incorporación a Eaton y teniendo en cuenta sus inquietudes políticas, le propuso comenzar la militancia en el PRTERP. ${ }^{22}$ Aquel, que había ingresado a la fábrica a fines de 1971, rápidamente se transformó en un referente entre sus compañeros de trabajo quienes lo eligieron como miembro de la Comisión Interna y delegado general de la planta. ${ }^{23}$ Alrededor suyo, el PRT-ERP construyó una célula que, compuesta por militantes extrafabriles, apuntaló su trabajo como delegado, realizando acciones de propaganda sobre la fábrica. Fundamentalmente, se realizaron volanteadas en la puerta del establecimiento y en los barrios aledaños, pero también actividades de propaganda armada como la toma de colectivos de la Línea 57, que transportaba a los trabajadores de la empresa, donde se los arengaban, se les repartían volantes y se les vendían periódicos. ${ }^{24}$

En 1973 se dio el mayor crecimiento del trabajo político-sindical perretista: a partir de la referencia de Panizza, durante la primera mitad del año, se conformó una célula de masas con dos obreros más ${ }^{25} \mathrm{y}$, a su vez, se realizó un trabajo de militancia en las distintas secciones de la planta que permitió, en el mes de junio, lanzar la agrupación sindical "Omar Dugetti", ${ }^{26}$

La agrupación, que se constituyó en la base político-sindical de la Comisión Interna, adhirió e integró el MSB, del cual el "Flaco" Panizza fue uno de sus principales dirigentes. Aquella agrupación fue la protagonista del principal conflicto sindical que vivió la planta: desatado por el aumento del precio del ticket del comedor, a principio del mes de julio, los trabajadores decidieron exigirle a la empresa un pliego de 13 reivindicaciones entre los que se encontraba la declaración del trabajo insalubre en algunas secciones. El conflicto duró 20 días y comprendió quites de colaboración,

${ }^{21}$ Fundamentalmente los vapores, el polvillo y las emanaciones propias de las fundiciones de metales hacían que en la mayoría de las secciones (Hornos, Noyería, Fusión, Rebajado y Desmoldeo) se produjera un ambiente insalubre cuyo riesgo principal era el saturnismo.

${ }^{22}$ L. Battistoti, comunicación personal, 2018. (esposa y compañera de Panizza); G. J. Panizza, comunicación personal, 2018.

${ }^{23} \mathrm{Su}$ papel destacado como dirigente es resaltado por Raúl Coria, obrero de la Eaton Ejes, que se contacta con el PRT-ERP a partir de su militancia. Por otro lado, Misael Aron Pajon, obrero que ingresa a Eaton Fundiciones en 1975, cuando Panizza ya no trabajaba más en la planta, recuerda que todos sus compañeros de fábrica destacaban a éste último como el principal dirigente de la fábrica: “el capo gremial que manejaba los hilos de Eaton" (R. Coria, comunicación personal, 2017; M. A. Pajon comunicación personal, 2018).

24 A. Elizalde, comunicación personal, 2018; DIPPBA, Mesa Ds, Varios, Leg. 1309.

${ }^{25}$ En total la célula estaba compuesta por tres trabajadores de Eaton Fundiciones y tres militantes extrafabriles que, haciendo centro esta fábrica, a su vez atendían el trabajo político de otras fábricas de la zona (A. Elizalde, comunicación personal, 2018)

${ }^{26}$ Omar Dugetti fue un obrero de la fábrica que había muerto en un accidente de trabajo y que, por ello, se transformó en un símbolo de la lucha contra las condiciones de trabajo. 
Stavale. "Construir el partido en las fábricas": la línea político-sindical del PRT-ERP ante la apertura democrática y...

asambleas masivas y paros. ${ }^{27}$ Además, contó con la intervención del ERP que decidió copar el establecimiento para fortalecer la demanda de los obreros y el trabajo político que venía desarrollando el partido. ${ }^{28}$ Aquella acción comprendió la toma de la guardia y la organización de una asamblea en la fábrica en la que participó casi la mayoría del personal y donde los combatientes arengaron consignas contra la patronal y repartieron volantes. Según los testimonios y el informe de la Dirección de Inteligencia de la Policía de la Provincia de Buenos Aires (DIPPBA), la acción habría recogido la simpatía y las vivas de gran parte de los obreros. ${ }^{29}$ Efectivamente, a partir de aquel hecho se consolidó la influencia de la organización al punto tal que, al día siguiente, una gran parte de los obreros de la planta decidió dibujarse en los cascos de protección una estrella de cinco puntas, en alusión al emblema del ERP. ${ }^{30}$

A partir de allí la agrupación creció notablemente y con ello la influencia del PRT-ERP. La organización logró organizar una cantidad importante de simpatizantes y colaboradores y, a través de la agrupación, logró movilizar a una delegación de obreros al V Congreso del Frente Antiimperialista por el Socialismo, realizado en la ciudad de Sáenz Peña, Chaco (NH, 53, 12/73). Además, comenzó a editar el Boletín Fabril "José Luis Castrogiovani”, el cual logró regularidad y constancia. ${ }^{31}$ De este modo, en esta experiencia, la influencia perretista se dio a través de la mayoría de las herramientas que el partido planteaba para el trabajo fabril. Sus límites estuvieron directamente relacionados a la abrupta y temprana irrupción de la represión patronal, policial y burocrática que, en menos de un año, descabezó el movimiento de base. ${ }^{32}$

${ }^{27}$ Declarar el trabajo como insalubre significaba pasar de una jornada de $8.30 \mathrm{hs}$ a una de $6 \mathrm{hs}$. Además, exigían que se mejore la ventilación de la planta y se garanticen mejores condiciones de trabajo en términos generales $(\mathrm{NH}, 46,8 / 73)$.

${ }^{28}$ La toma se realizó el 5 de agosto en medio de un quite de colaboración y el conflicto se resolvió cuatro días después cuando la patronal decidió concederle los 13 puntos planteados por los trabajadores (NH, 53, 12/73).

${ }^{29}$ Según un informe de la DIPBA, luego de retirado el grupo comando, un delegado de la fábrica (que no era Panizza) tomo la palabra y dijo: "Ya el movimiento obrero cuenta con un Ejército Popular que es el ERP, quien los apoya en la lucha contra la burocracia y la patronal" y pidió a los obreros que estrecharan filas y apoyasen a aquel ejército. Por otro lado otro activista de la planta habría manifestado a viva voz con respecto a los obreros que se habían mostrado remisos a participar de la asamblea que "a estos alcahuetes habría que fusilarlos." (DIPPBA, Mesa Ds, Varios, Leg. 1309)

${ }^{30}$ Este suceso fue recordado por tres testimonios distintos: Alberto Elizalde, miembro de la célula que trabajaba sobre Eaton, Gustavo José Panizza, y Misael Aron Pajón quien destaca que aquel hecho fue un hito recordado por los trabajadores de la fábrica. (A. Elizalde, comunicación personal, 2018; M. A. Pajon comunicación personal, 2018; G. J. Panizza, comunicación personal, 2018)

${ }^{31}$ De julio de 1973 a mayo de 1974 salieron 5 números del boletín que, además, continuó saliendo hasta el golpe de 1976 (EC, 117, 15/5/74; M. A. Pajon comunicación personal, 2018)

32 Aquello llevó a que la patronal y la "burocracia sindical" llevaran adelante una campaña feroz de amedrentamiento, represión y persecución contra el movimiento de base que incluyó: la incorporación de policías infiltrados en el personal, el matonaje de miembros del Comando de Organización, la "compra" de uno de los delegados de CIR que decidió pasar a colaborar con el SMATA y el secuestro de Panizza por parte de un comando no identificado de la policía durante el mes de enero, que terminó con su liberación gracias a la movilización de los 600 obreros de ambas plantas. Finalmente, a un mes de este último suceso el SMATA decidió retirarle los fueros de delegado a Panizza y la empresa decidió despedirlo, junto a otros dos activistas. Pese a diversos intentos de resistencia, la represión y la persecución descabezó al movimiento de base que recién en 1975 volvió a reactivar las luchas (El Mundo, 26/1/74; EC, 117, 15/5/74). 


\section{Rigolleau: la influencia perretista en un marco de amplia unidad}

La fábrica de vidrio Rigolleau se encuentra ubicada en la localidad de Berazategui y albergaba, para 1970, 3.000 trabajadores, siendo la fábrica del rubro más importante del país. En ella la conflictividad puede rastrearse desde 1968 por cuestiones de persecución ideológica, violación de convenios colectivos y despidos masivos (Centurion, 2013).

La primera experiencia de base estuvo a cargo de la lista Celeste, conformada fundamentalmente por obreros peronistas independientes, que logró triunfar en las elecciones de Comisión Interna en el año 1972. Aquella lista, sin embargo, terminó rompiéndose debido a la relación que entablaron algunos de sus dirigentes con la dirección nacional del sindicato, dirigida por el peronismo ortodoxo. En ese contexto, a fines de 1973, se formó la lista Naranja, lista opositora a la burocracia, formada por activistas que habían roto con la lista Celeste y militantes perretistas ${ }^{33}$, montoneros, trotskistas -PST-y maoístas -Vanguardia Comunista.

El trabajo político del PRT-ERP en la fábrica se inició a través de Luis Angelini, quien ingresó a trabajar el 18 de mayo de 1970. Según algunos testimonios, Angelini había ingresado al PRT en el año 1967 aunque, sin embargo, para el momento de ingresar a aquella fábrica estaba distanciado de la militancia, por lo que su entrada no habría sido en función de una tarea partidaria. De hecho, su reincorporación definitiva a la organización se habría dado un año después, en 1971 (Montero, 2017).

Según los testimonios, primeramente Angelini se ligó a la lista Celeste, lo que le permitió entablar vínculos con los dirigentes y militantes con los que luego fundó la lista Naranja. ${ }^{34}$ En ese sentido, el trabajo sindical perretista no se dio a través de una agrupación - como en el caso de Eaton-, sino a través de una lista amplia compuesta por militantes de diferentes corrientes políticas. ${ }^{35}$ Ello, lejos de limitar el trabajo político de la organización, fue lo que le permitió transformarse en una de las principales fuerzas políticas de la fábrica (Centurión, 2013). Angelini se transformó en uno de los principales dirigentes de la planta, reconocido por todos los trabajadores y por sus propios compañeros de la lista ${ }^{36}$; alrededor suyo logró construir células partidarias y un amplio círculo de influencia ${ }^{37}$, base desde la cual el PRT-ERP intervino con fuerza en el

\footnotetext{
${ }^{33}$ En base a los archivos de la DIPBA, desde 1973 se hallan registros de la presencia del PRT-ERP en la fábrica realizando acciones de distinto tipo, como volanteadas o toma de la planta (Mesa D(s), carpeta daños, legajo 2461)

${ }^{34}$ I. Pérez y C. Vidal, comunicación personal, 2017.

${ }^{35}$ Ignacio Pérez indica que la lista era tan amplia que lograba contener a todas las posiciones, y aunque a veces, dicha amplitud conducía a "discusiones maratónicas", inclusive en el seno de la CI, el funcionamiento era sumamente democrático.

${ }^{36}$ En palabras de Carlos Vidal, miembro de la Comisión Interna: "Luis fundamentalmente, a parte de su posición revolucionaria, era un carismático, que no es lo que caracteriza a la izquierda (...) Luis era un tipo querible, "el Gordo" llegaba a cualquier lado rodeado de compañeros (...) "El Gordo" era un destacado" (I. Pérez y C. Vidal, comunicación personal, 2017.)

${ }^{37}$ Por ejemplo, Ignacio Pérez dirigente de la Naranja, a partir de la referencia de Luis Angelini, se transformó en un simpatizante activo del PRT-ERP, formando parte de reuniones regularmente con las células del partido. (I. Pérez y C. Vidal, comunicación personal, 2017.)
} 
Stavale. "Construir el partido en las fábricas": la línea político-sindical del PRT-ERP ante la apertura democrática y...

principal conflicto de la planta. De hecho, debido a aquella influencia lograda, la Lista Naranja participó del II Plenario Nacional del MSB, algo que debido a la amplitud de aquella lista y la estrecha identificación de aquel movimiento con el PRT-ERP no resulta un dato menor.

Luego de un importante trabajo de base, la Naranja logró, en noviembre de 1974, ganar las elecciones de la Comisión Interna, y el 14 de enero de 1975 asumió sus funciones como la nueva conducción sindical de la fábrica. Sin embargo, poco después de ganadas las elecciones, el 5 de marzo, la seccional local del sindicato decidió intervenir el organismo. ${ }^{38}$ Esto motivó la reacción inmediata de los trabajadores, quienes decidieron iniciar una huelga de "brazos caídos" por tiempo indeterminado que se transformó, casi inmediatamente, en la toma del establecimiento. El conflicto se hizo extensivo a gran parte de la comunidad de Berazategui (fábricas vecinas, comerciantes, mujeres, etc.), que acudieron en diferentes momentos acercando su solidaridad con donaciones o actos en apoyo. Luego de una semana de lucha, el 12 de marzo, los obreros lograron llegar a un acuerdo con el sindicato nacional que decidió saltear la decisión de la seccional local y levantar la intervención, además de comprometerse a que un integrante de la Comisión Interna participara en las próximas discusiones sobre el convenio colectivo de trabajo. Por otro lado, también consiguieron que la patronal acceda a pagar los jornales perdidos a causa del conflicto.

Por las dimensiones que adquirió en la zona, la lucha de Rigolleau fue tomada como ejemplo por todas las organizaciones que intervinieron en ella. Para el PRT-ERP fue muy importante no sólo por ser una muestra contundente de la reactivación de las luchas sino también por el nivel de inserción que había logrado en la fábrica. Mediante diferentes actividades de propaganda, la organización se hizo notar a través de pintadas del ERP al interior del establecimiento, el izamiento de su bandera en el mástil de la planta y otro tipo de acciones similares. ${ }^{39}$ Asimismo, en el trascurso del conflicto, un comando del ERP copó el depósito de la empresa y quemó su stock. Luego, los combatientes tomaron la guardia de planta e intervinieron en el final de una asamblea de los trabajadores.

\footnotetext{
${ }^{38}$ La nueva CI una vez en funciones comenzó a levantar un petitorio con puntos reivindicativos como la formación de la "4. ${ }^{\text {a }}$. Brigada" (turno especial para hacer horarios de relevos), el pago de francos y un aumento salarial de 100.000 pesos. Como parte de esta demanda convocó a una asamblea con abandono de tareas donde se resolvió realizar un paro de dos horas hasta tanto se atendieran las reivindicaciones, lo que generó la reacción de la seccional local del sindicato. La intervención fue justificada con la excusa de que dichas medidas se habían tomado a espaldas del sindicato (I. Pérez y C. Vidal, comunicación personal, 2017.)

${ }^{39}$ En los informes de inteligencia de la DIPBA pueden verse distintas referencias a la presencia del PRTERP en la fábrica durante el conflicto. Por ejemplo se destaca: "fueron observados de forma notoria, estandartes con insignias y nombre de Montoneros y 'ERP'"; se adjuntan volantes del ERP que habían sido repartidos en puerta de fábrica ("Al Pueblo Argentino"). (Archivo DIPBA, Mesa B, Factor gremial, Berazategui, Careta 18 bis, Leg. 14). Las pintadas del ERP llevaban consignas como "Marino traidor" y "Cuidado patrones, el ERP vigila". También se realizaron quemas de muñecos con la insignia norteamericana y el nombre de Marino, secretario general de la seccional local del sindicato del vidrio (PST, 1975c; EC, 162, 7/4/75).
} 
Ahora bien, a diferencia del caso de Eaton, la intervención militar de la organización tuvo distintas valoraciones. Por su parte, para el PRT-ERP la acción habría sido recibida "calurosamente por los trabajadores en un clima de entusiasmo". Pero para algunos dirigentes de la Naranja, como Carlos Vidal e Ignacio Pérez, la acción no había ayudado al conflicto y no había caído bien entre los trabajadores ya que había ido en contra de la resolución de asamblea de no dañar las máquinas e instalaciones de la empresa durante la toma. ${ }^{40}$ En la opinión de estos militantes, se había tratado de una acción "descolgada", es decir, alejada del espíritu de la toma. Una opinión similar puede encontrarse en el balance del PST, organización que rechazaba la lucha armada por considerar que sustituía las acciones de los obreros. Sin embargo, al mismo tiempo, esta organización también reconocía que había algunos "proles" que simpatizaban con ese tipo de acciones. De hecho, a modo de autocrítica consideraban que dichas simpatías habían llevado a que sus propios militantes no pudieran denunciar públicamente la acción ante los trabajadores (PST, 5/3/75).

Por otro lado, y en esa misma dirección, el PST reconocía la influencia del PRT-ERP en el conflicto, en tanto habían sido éstos quienes habían logrado convencer a la Comisión Interna de pasar de la huelga de "brazos caídos" a la toma de la planta. ${ }^{41}$ Además, planteaban que éstos habían sido, junto a Vanguardia Comunista, los únicos que le habían dado importancia a la ligazón del conflicto con la comunidad berazateguense. Esto último coincide con las palabras de Ignacio Pérez, quien rescata que el PRT-ERP, a diferencia del PST, tenía una línea sindical de mucha amplitud y constantemente preocupada por sumar apoyos y voluntades. ${ }^{42}$ Así, pese a la polémica que pudo haber suscitado la acción del ERP, todos coinciden en destacar la influencia perretista en la planta, durante y luego del conflicto.

No obstante, al igual que en Eaton, aquella experiencia duró poco tiempo. A mediados de marzo de 1976, la empresa despidió a 217 obreros, entre los que se encontraban todos los integrantes de la lista Naranja, y la reacción ante semejante medida estuvo fuertemente condicionada por el golpe de estado instaurado pocos días después. ${ }^{43}$

\footnotetext{
${ }^{40}$ I. Pérez y C. Vidal, comunicación personal, 2017.

${ }^{41}$ Según estos boletines, a lo largo del conflicto el PST habría sostenido varias polémicas con el PRT-ERP: una de ellas, y la más importante, era sobre qué estrategia darse ante la burocracia sindical nacional. Así, mientras el PST habría planteado la línea de diferenciar a la burocracia local de la nacional para lograr destrabar el conflicto, el PRT-ERP habría planteado que había que enfrentarlas de igual manera porque se trataba del "burócrata mayor". Esta polémica la habría ganado el PST ya que, de hecho, fue debido a la intervención de Castillo, Secretario General Nacional del gremio del Vidrio, la que había permitido destrabar el conflicto (PST, 1975a; PST, 1975b; PST, 1975c).

${ }^{42}$ I. Pérez y C. Vidal, comunicación personal, 2017.

${ }^{43}$ Luego de los despidos, los referentes de la Naranja lograron realizar una asamblea de urgencia donde se animó a continuar con la resistencia, pero sin que de allí surgiera un plan de lucha. Luego del despido Luis Angelini comenzó a trabajar en un taller de fundición pero, al poco tiempo, fue nuevamente despedido. El 18 de mayo de 1977 es secuestrado de su casa y aún hoy continúa desaparecido (Montero, 2017).
} 


\section{ARTÍ́CULOS}

Stavale. "Construir el partido en las fábricas": la línea político-sindical del PRT-ERP ante la apertura democrática y...

Mercedes Benz Argentina: entre las prescripciones partidarias y el criterio de la militancia fabril

La planta de Mercedes Benz Argentina (MBA), estaba ubicada en el partido de La Matanza y ocupaba aproximadamente a 4.000 operarios, siendo una de las principales terminales automotrices del país. En ese sentido, se transformó en un objetivo importante para el PRT-ERP que definía a aquella industria como la "columna vertebral de toda la industria argentina y de la política imperialista" y, por ende, "estratégica" para realizar trabajo político (EC, 140, 23/10/74).

La lucha de sus trabajadores pasó principalmente por la disputa de los organismos sindicales de base, dominados históricamente por la Lista Verde, dirección nacional del SMATA. Desde fines de la década del sesenta se registra la presencia de organizaciones de izquierda al interior de la planta, aunque fue a partir de la década del setenta que se desarrollaron las diferentes organizaciones de la nueva izquierda. Entre ellas, se destacó Montoneros -en un primer plano-y el PRT-ERP, que contó con dirigentes importantes y una cantidad considerable de militantes. ${ }^{44}$

Según Casco Peebles y María Agustina Lenuda (2016), la actividad del PRT-ERP en la fábrica comenzó en 1971, lo que coincide con el testimonio de Julio D'Alessandro quien habría sido, junto a otro trabajador, el primero que se puso en contacto y se sumó a la organización a fines de aquel año. Según el relato de este último, habría sido el "prestigio" que el PRT-ERP había ganado en años de dictadura lo que lo llevó a buscar el contacto con la organización, el cual se dio debido a la actividad de propaganda que los perretistas desarrollaban en las puertas de la fábrica. ${ }^{45} \mathrm{~A}$ partir de allí, comenzó a organizarse el partido y, al poco tiempo, se incorporó Hugo Crosatto, quien se transformó en uno de los principales dirigentes sindicales. ${ }^{46}$ Este núcleo de militantes comenzó a activar gremialmente y participó, en 1974, junto al resto del activismo fabril, de un conflicto que derivó en la ocupación de la planta. ${ }^{47}$ Como resultado de aquel

\footnotetext{
${ }^{44}$ En un segundo plano de importancia se ubicaron el Partido Comunista y del PST, fuerzas políticas que primeramente se instalaron en MBA; por último, en un tercer nivel de importancia, se hallaban el Peronismo de Base, el Partido Comunista Revolucionario y el PRT-Fracción Roja/GOR.

45 “Estábamos buscando yo y otro compañero como engancharnos, y cuando logramos engancharnos le dije a uno de los que volanteaban y rajaban que quería hablar con ellos (...) Después de ahí empezamos a hacer la célula, había unas ganas y una movilización impresionante de luchas antiburocráticas y políticas en esos años, entonces fue fácil. Y como no había que tener todo en manos de un compañero, en el caso mío, cuando enganchaba algún compañero lo pasaba al responsable y se hacían otro tipo de célula." (J. D’Alessandro, comunicación personal, 2014).

46 "A mí me engancharon ellos adentro de la fábrica. Yo siempre milité en el PRT por la fábrica, no porque venía desde afuera. Ya te digo, en el '72 (...) El proceso es por un compañero, que laburaba en el sector que estaba yo, que siempre charlábamos. Estábamos muy distanciados con la máquina pero charlábamos siempre en el comedor. En alguna oportunidad nos juntábamos y charlábamos y ante su pregunta de si yo militaba en algún lado le dije que no, y me dijo: ‘¿y te gustaría militar?’, a lo que le respondo: 'mira, si me decido va a ser por el PRT'. Ante esta posición él se define como del PRT y me dice 'cuando quieras y donde quieras yo te llevo con mi referente y charlamos un rato' $¡ Y$ así empecé! Nos juntamos en la casa de mi abuela, en la casa de él en San Justo y empecé a militar en el PRT" (H. Crosatto, comunicación personal, 2017)

${ }^{47}$ El mismo se desató debido a la falta de refrigeración en la sección de tratamientos térmicos. Ante la falta
} 
proceso, surgió una lista de base que disputó y ganó las elecciones de la Comisión Interna realizadas en el mes de septiembre de aquel año. Sin embargo, aquella lista, hegemonizada fundamentalmente por el peronismo revolucionario, fue desbaratada por presión del SMATA que terminó interviniendo el organismo gremial.

Luego de aquella experiencia, la intervención sindical adquirió nuevas características: la misma ya no se dio a través de una lista (ni de una agrupación), sino de un volante clandestino firmado como Cuerpo de Representantes Obreros y Empleados de Mercedes Benz Argentina (CROEMBA). Se trataba de una herramienta de propaganda impulsada por los perretistas junto a activistas independientes y al resto de las organizaciones, en la que se fijaban posiciones sobre la situación gremial y los problemas laborales que se vivían en la fábrica, buscando representar las principales preocupaciones de los trabajadores y construir una opinión alternativa a la de la Lista Verde. Aquel material se ajustaba a la realidad de la fábrica y su movimiento de base, en tanto estaba pensado para evitar la persecución política patronal y sindical, al mismo tiempo que para garantizar la coordinación entre las diferentes expresiones políticas manteniendo la agitación entre los obreros. En esa línea, los militantes perretistas descartaron la opción de construir una agrupación sindical ligada al PRT-ERP y, como consecuencia, no participaron del MSB. ${ }^{48}$

Ello no impidió, sin embargo, que la organización creciera al interior de la planta. Por el contrario, según recuerda Ricardo Hoffman ${ }^{49}$, obrero perretista, para fines del año 1974 el PRT-ERP contaba, aproximadamente, con seis células de tres o cuatro miembros cada una, y una red de simpatizantes bastante más amplia, con presencia en la mayoría de las secciones. Incluso, para 1975, habría logrado organizar una dirección partidaria con las características de un Comité Fabril..$^{50}$ Además, habría contado con dos escuadras militares, una que pertenecía a la estructura formal del ERP y respondía a la dirección regional, y otra, impulsada por "los pesados de la fábrica", un grupo de trabajadores "dispuestos a combatir" pero no a entrar al partido ${ }^{51}$, que conservaba mayor independencia y menor organicidad.

La influencia a nivel gremial también fue muy importante. De hecho, en la elección de las comisiones paritarias convocadas en marzo de 1975, tres de los seis integrantes elegidos por MBA fueron militantes perretistas $\mathrm{y}$, unos meses más tarde, Hugo

de respuesta los trabajadores ocuparon el establecimiento con las autoridades adentro, lo que obligó a la firma a comprometerse a resolver el problema (Tomuschat, 2003, p.33).

${ }^{48}$ Ello no es algo que resulte menor si para 1975 la organización consideraba que "la presencia de la actividad del Partido en lo específicamente sindical la hacemos a través del MSB o de las agrupaciones en las cuales trabajamos" (PRT, 1975).

${ }^{49}$ La incorporación de Ricardo Hoffman se dio a mediados de 1974 y, a diferencia de Crossato y D'Alessandro, su contacto con la organización se dio por la referencia política y personal de uno de sus compañeros de trabajo (R. Hoffman, comunicación personal, 2017).

50 "Era una organización que abarcaba horizontalmente [la fábrica]. O sea que no solamente estábamos en la parte obrera, también estábamos en la administración y en el servicio médico." (R. Hoffman, comunicación personal, 2017).

${ }^{51}$ R. Hoffman, comunicación personal, 2017 
Stavale. "Construir el partido en las fábricas": la línea político-sindical del PRT-ERP ante la apertura democrática y...

Crossatto se transformó en uno de los principales dirigentes del conflicto más importante de la empresa: una huelga de 22 días, decretada el 8 de octubre de ese mismo año.

Aquella huelga fue declarada en rechazo a la disposición del SMATAde descontar un jornal a los trabajadores para la caja del gremio. Al conocer aquella disposición, una cantidad importante de trabajadores se reunieron en la puerta de la oficina de los interventores sindicales exigiendo la anulación de aquella medida; además, aumentos salariales indexados a la inflación, el fin de la intervención a la Comisión Interna y el llamado a elecciones. En ese contexto, reunidos en asamblea, los trabajadores decidieron, por unanimidad, ir a la huelga y también eligieron una Comisión Interna provisoria, compuesta por nueve miembros (que pasó a conocerse como "el grupo de los 9"), entre los que figuraba Crosatto. ${ }^{52}$

Debido a la contundencia de la medida la empresa decidió el despido 117 trabajadores entre los que se incluían la totalidad del "grupo los 9", lo que motivó una radicalización de la lucha. Bajo la consigna "los 4.000 adentro o los 4.000 afuera", los trabajadores formaron un Comité de Lucha (órgano de dirección del conflicto), editaron un boletín de huelga y organizaron distintas comisiones para afrontar el conflicto (autodefensa, fondo de huelga, solidaridad, etc.). La participación de la mayoría de los trabajadores de la planta, el nivel de organización alcanzado y la solidaridad de la población aledaña y de trabajadores de otras fábricas fueron debilitando la posición de la patronal que se vio finalmente quebrada con el secuestro de Franz Metz, gerente de la compañía, por un comando montonero el 24 de octubre, a 16 días de iniciada la huelga. A partir de allí, la posición de los trabajadores fue creciendo y luego de una movilización a las oficinas centrales de MBA el día 29, todas las reivindicaciones de los trabajadores fueron concedidas.

Lo interesante allí, es que pese a que el PRT-ERP públicamente reconoció que el secuestro había ayudado a "robustecer y dar nuevas perspectivas" a la lucha, y si bien el ERP había realizado acciones menores de intimidación a la empresa en el marco del conflicto, los militantes perretistas manifiestan no haber estado de acuerdo con la acción montonera e incluso haber rechazado la propuesta del propio partido de realizar una acción semejante. ${ }^{53}$ Así, en un claro contrapunto con la línea del partido, para los militantes, el conflicto obrero debía ser resuelto por los obreros y no por la intervención externa de una organización revolucionaria. Desde sus puntos de vista ello violaba el "acuerdo básico" de no dejar que los partidos interfiriesen en la vida gremial de la fábrica.

Luego del triunfo de la huelga, el PRT-ERP continuó consolidando su influencia entre los trabajadores. Desde la Comisión Interna y el Comité de Lucha, fueron parte protagonistas de las amplias conquistas y conflictos sindicales que se dieron en los meses posteriores al triunfo. Sin embargo, como en el caso de Rigolleau, aquel proceso se vio violentamente interrumpido por el golpe de estado de marzo de 1976. Luego de un año de resistencia obrera mediante quites de colaboración, trabajo a desgano y sabotaje

\footnotetext{
${ }_{52}$ El "grupo de los 9" estuvo compuesto por dos militantes de la JTP, uno del PRT-ERP y el resto eran activistas independientes.

${ }^{53}$ R. Hoffman, comunicación personal, 2017; H. Crosatto, comunicación personal, 2017
} 
desde la clandestinidad, el partido fue desarticulado casi en su totalidad para mediados de 1977 debido a las renuncias y las desapariciones forzadas de varios activistas.

\section{Conclusión}

En el presente artículo hemos intentado avanzar en la reconstrucción de la línea político-sindical del PRT-ERP, para luego analizar, a través de tres ejemplos, como fue traducida en la práctica por sus militantes fabriles. Como hemos planteado, la concepción sindical de la organización fue evolucionando a lo largo de los años y a la luz de los conflictos, pasando de una "desconfianza" y subestimación inicial a darle un lugar de peso en su práctica política. Así, sin dejar de inscribirla en su estrategia de guerra revolucionaria, la organización fue complejizando su línea y perfeccionando las herramientas organizativas para intervenir en las fábricas. Aquello se dio fundamentalmente cuando, en el marco de la apertura democrática y del proceso de rectificación de la "desviación militarista", la organización previó que la movilización de masas pasaría fundamentalmente por la lucha reivindicativa, por lo que lograr protagonismo en las mismas pasó a ser una tarea prioritaria.

En ese marco se dispuso a construir "el partido en las fábricas", lo que supuso la disposición de un modelo organizativo y de una serie de herramientas político-sindicales con las que buscó "profesionalizar" su militancia en los establecimientos. Para ello, los militantes fabriles debían apuntar a replicar la estructura partidaria al interior de los establecimientos, construyendo células con tareas específicas, organizando el radio de simpatizantes, publicando boletines fabriles y constituyendo una dirección de la fábrica (los comités fabriles) que dirigiese la actividad en las plantas. El objetivo estaba puesto en no reducir la actividad fabril sólo a la actividad sindical, abordando "multilateralmente" las tareas políticas, militares y sindicales.

En ese sentido, impulsó agrupaciones gremiales, promovió un movimiento nacional antiburocrático como el MSB y, en paralelo, desarrolló una intensa actividad militar e, incluso, llegó a promover la formación de una tendencia sindical clandestina y armada (la TOR “22-8”) que, sin embargo no prosperó. Desde el punto de vista de la organización, la incorporación de la violencia revolucionaria en las luchas reivindicativas era uno de los vehículos fundamentales para ayudar a que los trabajadores dieran el "salto" de lo reivindicativo a lo político. Así fue que la propaganda armada del ERP, que iban desde tomas de guardia y reparto de volantes hasta acciones de apoyo a los conflictos, se transformó en una de las prácticas distintivas de la intervención perretista en las fábricas.

No obstante, como vimos, no en todos los casos los militantes tradujeron de la misma manera las prescripciones partidarias. Si bien a grandes rasgos, en las experiencias reconstruidas, la organización logró contar con dirigentes sindicales en las comisiones internas y los cuerpos de delegados así como edificarse de acuerdo con la estructura orgánica básica diseñada por el partido, la intervención sindical y militar varió según la realidad de cada establecimiento. Así, en el caso de Eaton Fundiciones los militantes impulsaron una agrupación, mientras que en Rigolleau intervinieron a través de una lista amplia compuesta por militantes de otras corrientes y en MBA a través de 
Stavale. “Construir el partido en las fábricas”: la línea político-sindical del PRT-ERP ante la apertura democrática y...

una herramienta totalmente heterodoxa, como fue el CROEMBA. Del mismo modo, en este último caso, decidieron no encuadrarse en el marco del MSB ya que, según sus militantes, ello hubiera significado serias dificultades para coordinar la acción con otros grupos. Es que en MBA, a diferencia de los ejemplos de Eaton y Rigolleau, pareciera haber habido una forma específica de entender la relación partido-fábrica basada en una distinción explícita de dos niveles de intervención: la "política", que podía y debía ser abordada por el partido, a través de sus herramientas tradicionales; y la gremial, donde quienes decidían los criterios eran los obreros y no el partido.

Estas diferencias también se reflejaron en la actividad armada. En Eaton Fundiciones y Rigolleau, el accionar del ERP fue destacado durante los principales conflictos que vivieron las plantas, aunque con resultados distintos ya que, en el primer caso, le habría ayudado a extender la influencia de la agrupación y de la organización mientras que, en el segundo, sus efectos habrían sido más discutidos, suscitando polémicas y percepciones distintas entre los huelguistas. No obstante, en ambos casos la intervención parece haber estado en consonancia con el trabajo político-sindical que sus militantes venían realizando en las fábricas. En cambio, en el caso de MBA, los militantes se negaron a que la organización realizase acciones de gran envergadura en el marco de la huelga e, incluso, según los testimonios, estuvieron en desacuerdo con el secuestro montonero que destrabó el conflicto, en clara disidencia con el balance público que realizó el PRT-ERP.

Como hemos intentado retratar, a partir de la reconstrucción de estos casos, las modalidades en que se dio la intervención fabril del PRT-ERP fueron diversas y variaron en función de la experiencia de sus militantes. Consideramos, en ese sentido, que fue en esa práctica concreta en que se fraguó la línea sindical perretista y, por ende, es allí donde debe estudiarse cuál y cómo fue el vínculo entre esta organización y el movimiento obrero argentino.

\section{Fuentes}

Archivo de la DIPPBA y el Centro de Documentación de la Comisión Provincial por la Memoria.

El Combatiente (EC) [números varios]. Recuperado de: www.eltopoblindado.com

Nuevo Hombre (NH). En Nuevo Hombre: edición facsimilar. Buenos Aires: Biblioteca Nacional.

PRT. (1968). "El único camino hasta el poder obrero y el socialismo". En De Santis, D. (2004), A vencer o morir. PRT-ERP. Documentos, Tomo I, Vol. I. Buenos Aires: Nuestra América.

PRT. (1970). "Resolución de fundación del Ejército Revolucionario del Pueblo". En: De Santis, D. (2004), A vencer o morir. PRT-ERP. Documentos, Tomo I, Vol. I. Buenos Aires: Nuestra América.

PRT. (1972a). "Boletín Interno nro. 25". Mattini, Luis (2003). Hombres y mujeres del PRT-ERP de Tucumán a la Tablada, La Plata: De la Campana, 2003. 
PRT. (1972b). "Resoluciones del Comité Central de diciembre de 1972”. En: De Santis, 2006. PRT. (1973). "Boletín Interno nro. 35, 16 de enero de 1973”. En De Santis (2010), La Historia del PRT-ERP por sus protagonistas. [CD-ROM]. Buenos Aires: A formar filas editora guevarista.

PRT. (1974a). “Boletín Interno nro. 63, julio de 1974”. En: CD “La Historia del PRTERP por sus protagonistas".

PRT. (1974b). "El partido en la fábrica. Hacia el VI Congreso" En: CD "La Historia del PRT-ERP por sus protagonistas".

PRT. (1975). “Boletín Interno del PRT-ERP nro. 85”. En: CD “La Historia del PRT-ERP por sus protagonistas".

PST. (1975a). "Boletín Interno 5/3/75". Recuperado de: www.fundacionpluma.info

PST. (1975b). "Boletín Interno. Sindical. Comité Central 5/5/75" En: www. fundacionpluma.info

PST. (1975c). “Boletín Interno 12/5/75”. Recuperado de: www.fundacionpluma.info

\section{Referencias bibliográficas}

Balvé, B. \& Balvé, B. (1989). El '69. Huelga política de masas. Buenos Aires: Ed. Contrapunto. Carnovale, V. (2011). Los combatientes. Historia del PRT-ERP. Buenos Aires: Siglo XXI Editores.

Casco Peebles, M. \& Lenuda M. A. (2016). "Conflicto obrero y acción guerrillera. La huelga en Mercedes Benz en 1975 y el secuestro de un nazi”, Archivos, 9, 97-116. ISSN: 2313-9749.

Centurión, B. N. (2013). “Cuidado patrones, el ERP vigila. Un acercamiento a los vínculos existentes entre el PRT-ERP y la clase obrera (1974-1975)", Trabajadores: Ideología y experiencias en el movimiento obrero, 4, 92-113. ISSN: 1853-6735.

De Santis, D. (2004). A vencer o morir. PRT-ERP. Documentos, Tomo I, Vol. I. Buenos Aires: Nuestra América.

De Santis, D. (2006) A vencer o morir. PRT-ERP. Documentos, Tomo I, Vol. II Buenos Aires: Nuestra América.

De Santis, D. (2010). La historia del PRT-ERP por sus protagonistas. Buenos Aires: A formar filas editora guevarista.

Ducid, M. (2014). Lucha obrera, conflicto sindical y organización armada: El caso de la Juventud Trabajadora Peronista de Propulsora Siderúrgica., [Tesis de grado, FaHCE-UNLP], Memoria Académica.

Guevara, E. (1964). Prólogo al libro de Vo Nguyen Giap, Guerra del pueblo, ejército del pueblo. La Habana: Editora Política.

Inchauspe, L. H. (2007). 'La organización militar del pueblo.' El PRT-ERP, guerra y política en la Córdoba de los setenta. XI Jornadas Interescuelas Departamento de Historia, Facultad de Filosofía y Letras, Tucumán.

Izaguirre, I., \& Aristizábal, Z. (2002). "Las luchas obreras 1973-1976”. Documento de trabajo, 17. ISBN 950-29-0594-6. 
Stavale. “Construir el partido en las fábricas”: la línea político-sindical del PRT-ERP ante la apertura democrática y...

Izzaetta, M. (2015). "De lo pequeño a lo grande": el PRT-ERP y las acciones armadas consideradas como cualitativamente menores (1971-1976)." Contenciosa, 5. ISSN: 2347-0011.

Löbbe, H. (2006). La guerrilla Fabril. Clase Obrera e izquierda en la Cooridnadora de Zona Norte del Gran Buenos Aires (1975-1976). Buenos Aires: Ediciones RyR.

Lorenz, F. (2013). Algo parecido a la felicidad. Una historia de la lucha de la clase trabajadora durante la década del setenta (1973-1978). Buenos Aires: Edhasa.

Montero, H. (2017). "Luis Angelini. Un rompecabezas en clave naranja", Sudestada de colección, 13.

O’Donnell, G. (1982). El Estado Burocrático Autoritario. Buenos Aires: Ed. De Belgrano.

Ollier, M. (1986). El fenómeno insurreccional y la cultura política argentina. Buenos Aires: Centro Editor de América Latina.

Pacheco, J (2015). "Análisis de la militancia sindical de Montoneros: La Juventud Trabajadora Peronista y sus luchas", e-l@tina, 13, 50, 20-44. ISSN: 1666-9606.

Pozzi, P. (2004). Por las sendas argentinas... El PRT-ERP. La guerrilla Marxista. Buenos Aires: Eudeba.

Scopetta, L. \& Torres, P. (2014). "La apuesta armada. Notas sobre la política sindical del PRT-ERP en el Gran Rosario (1965-1976)". Mimeografía inédita, Biblioteca de la Escuela de Historia, Facultad de Humanidades y Artes, Universidad Nacional de Rosario, Argentina.

Scopetta, L. \& Torres, P. (2018). "La política sindical del PRT-ERP: notas sobre una búsqueda (1965-1976)". En: S. Simonassi \& D. Dicósimo, Trabajadores y sindicatos en Latinoamérica, (pp. 83-99). Buenos Aires: Imago Mundi.

Stavale, S. (2017). Entre la lucha ideológica y la unidad de acción en las fábricas. La relación del Partido Revolucionario de los Trabajadores con la Tendencia Revolucionaria del Peronismo en los años 70, Izquierdas, 36, Recuperado de: http://www.izquierdas.cl/images/pdf/2017/n36/art4.pdf-

Stavale, S. (2019). Perros en las fábricas: La politica sindical del PRT-ERP, sus prácticas y la experiencia de sus militantes en fábricas del Gran Buenos Aires, 1973-1976. [Tesis de doctorado. Facultad de Humanidades y Ciencias de la Educación, UNLP], Memoria Académica.

Stavale, S. (2020a). 'De cada fábrica una fortaleza': el PRT-ERP en Talleres Electromecánicos Norte S.A (TENSA), 1973-1976, Revista del Programa de Investigaciones sobre Conflicto Social, 3, 24, recuperado de: https://publicaciones. sociales.uba.ar/index.php/CS/article/view/6258

Stavale, S.(2020b).ElMovimiento Sindical deBase: apuestasindicaldelPRT-ERP, Sociohistórica, 46, http://www.memoria.fahce.unlp.edu.ar/art_revistas/pr.12026/pr.12026.pdf

Tomuschat, C. (2003). "Mercedes Benz Argentina durante la dictadura militar (19761983)", Informe.

Tortti, M.C. (2014). "La nueva izquierda argentina: la cuestión del peronismo y el tema de la revolución". En Tortti, M.C (Directora), La nueva izquierda argentina (1955-1976): socialismo, peronismo y revolución, (pp.15-35). Rosario: Prehistoria Ediciones.

Vezzeti, H. (2009). Sobre la violencia revolucionaria. Memorias y olvidos. Buenos Aires: Siglo XXI. 